of the coast plain, farther west. Tripoli alone has a defensible position and a permanent harbour, for a low ridge of tabular limestone protrudes beyond the long beaches, and bending eastward encloses a considerable port. Leptis in earlier times had been the chief centre, but its harbour was constructed in the mouth of a small stream, and this has silted and destroyed it: the coast also has risen some twenty feet since Roman times, and the quay wall, with lighthouse, boat-steps and bollards, is high-and-dry.

Unlike Cyrenaica, which came into Greek hands without trouble with the Libyan natives, Tripolitania was from the first a cause of quarrel between Greeks and Carthaginians, and the natives supported the latter. For long it was simply 'the depots' (Emporia); but after the fall of Carthage in 146 B.c. the Roman protectorate made it accessible, and it became a great source both of grain and of oil. Like Cyrenaica, too, it attracted many Jewish traders. At the end of the third century A.D., Leptis gave Rome one of its most efficient emperors, Septimius Severus, who did not forget his birthplace, and built a palace for his wife, and other impressive buildings. These, overlooking the harbour, became buried in sand dunes when disaster came, so rapidly and completely that after recent excavation they rival Pompeii and Algerian Timgad as an illustration of Roman culture in its later prime.
Neither Tripoli nor Zlieten have monuments to compare with those of Leptis; but the four-faced triumphal arch built for Marcus Aurelius in 164 A.D. in the civic centre of $\mathrm{Ea}$ is a fine monument of its kind ; and at Zlieten the ground plan of the principal buildings can be traced, and has been partly excavated. The mosaics in private houses, though not so large or splendid as those of Sousse (Hadrumetum) in Tunisia, are among the best in North Africa.

When Tripoli fell to the Arabs, the conquerors were amazed that indemnities and tribute were paid in gold coin ; but the citizens explained: "This is what people pay for our oil". How extensive this oil industry became is shown by hundreds of oil farms with stone-built presses, all along the Tarhuna highland. When first visited by travellers, they were described as 'megalithic'-and indeed their stones are very large; but they are based on Roman concrete, on sites with Roman masonry and potsherds, so there is no doubt of their date; the whole process of milling and pressing the olives is depicted on Roman reliefs and frescoes; and the same type of lever press has been seen at work by a modern traveller in Morocco. After the present turmoil, one may hope for re-establishment of this characteristically Mediterranean industry in what seems to have been one of its earliest and most productive homes.

\title{
SCIENCE AND THE CITIZEN: THE PUBLIC UNDERSTANDING OF SCIENCE
}

\begin{abstract}
$T^{1}$ HE Division for the Social and International Relations of Science of the British Association held a conference at the Royal Institution in London during March 20-21 to consider ways and means for increasing the public understanding and appreciation of science. For more than a hundred years the British Association through its annual conferences has endeavoured to introduce science to the citizen, but the fact remains that to-day, in the midst of a scientific age, science and the citizen are still very insufficiently acquainted. As was so frequently stressed during the course of the conference, we are living in an era in which the discoveries of science are becoming an essential constituent of our everyday life, and an understanding of the spirit and service of science is of the utmost importance for the people and its leaders if our civilization is to survive.
\end{abstract}

\section{The Exposition of Science}

Sir Richard Gregory, president of the Association, in opening the conference, said that since the be. ginning of history there has always been a lag between stages of scientific knowledge and social and moral wisdom. He considers that what is particularly needed to-day is the promotion of public interest in the close relationships of natural science with other humanistic studies which influence the thoughts and actions of all citizens.

A message from Sir John Anderson, Lord President of the Council, emphasized the vital contributions which science will have to make to the solution of post-war problems. It pointed out that much harm may be done if those without scientific training are encouraged by extravagant advocacy of the marvels of science to expect from science alone remedies for all the social problems which will have to be faced.
A message from Prof. Joffe, vice-president of the Academy of Sciences of the U.S.S.R. (see below), was received but unfortunately not in time to be read to the meeting, and another from Dr. Harlow Shapley and Mr. Watson Davis of Science Service, suggesting immediate international co-operation in the distribution and popularization of scientific information.

Sir Henry Dale, who presided, reminded the audience of some points in the history and associations of the Royal Institution, which was formed with aims closely resembling those to be considered by the conference. He said that the public understanding of science needs for its achievements the co-operation of the two parties concerned-the men of science and the people. The former must study all the means available for interpreting and expounding their prob. lems and achievements, and the whole people must be prepared to receive the message. If Great Britain is to play its part in the civilization now in the making and to keep step in the march of progress with the other great world communities, nothing will suffice short of a recasting of our schemes of education. Science must be given its proper and central place at every stage in elementary, secondary, university and adult education.

Sir Lawrence Bragg dealt with the difficulties of getting the scientific message to the public. Scientific workers are often accused of being too technical in their presentation of their subject. There is some truth in this, but the real trouble is that science has not been regarded as an essential part of a balanced education. We have a number of fine industrial laboratories in Great Britain, but the industrial leaders more often owe their positions to their commercial and financial ability than to their 
technical ability. In industry, scientific men are too often regarded rather as experts to be called in when there are troubles, not as colleagues to be called in when making plans. He advocated greater personal contact between scientific consultants and members of the Government, rather than the appointment of advisory committees.

Sir Lawrence gave some useful advice as to how to give a popular scientific lecture, his own talk being an admirable illustration of the points he mentioned.

Prof. Allan Ferguson gave an account of the great expositors of science in the eighteenth and nineteenth centuries with particular reference to Faraday and Huxley, whose passionate love of truth and clarity of expression are eternal examples for future generations to emulate.

Dr. Arnold Raestad, former Minister of Foreign Affairs to the Norwegian Government and now governor of the Norwegian Bank, spoke about the international dissemination of science. He formerly presided over the committee of scientific men appointed in 1938 by the League of Nations (through the International Institute of Intellectual Co-operation in Paris) to consider the means of improving, by organizational measures, the way in which the results and methods of science may be presented to a general public. All modern media of current presentation were considered-lectures, press, films, exhibitions and radio. The committee recommended the creation of an international centre for scientific information. The War has interrupted these efforts, but war-time experience has only emphasized the urgent necessity of such work, and it is to be hoped that as soon as conditions permit the committee will renew its attempt to bring a knowledge of international scientific progress within the reach of every citizen.

Mr. J. A. Lauwerys spoke about museums and the interpretation of science. He considers that the national museums of Great Britain are second to none in the world, and two hundred others are good. But the remaining six hundred are junk shops in which curators, generally very poorly paid, collect salvage. They bear very obviously the marks of the social system which has given them birth. Even among the good museums, science is but poorly represented. There is not a single planetarium in the whole country, though many German and American cities possess good ones.

In this matter, we have much to learn from the United States. There, a great many museums are attempting to present ideas to the public, instead of merely housing and preserving collections. Their methods of display, based upon the fundamental laws of effective display, are often superb. They use the resources of modern engineering and craftsmanship, and they have learned much from the art of the modern window-dresser. Materials are presented so as to show their functions; exhibits are presented in progressive stages of development; the displays are integrated and the relationship between what is shown and contemporary civilization is plain.

Mr. Lauwerys advocates a Museum of Science as one of the most important buildings of a great eivic centre in each of our cities after the War.

\section{Radio and Cinema}

Sir Allan Powell, chairman of the Board of Governors of the B.B.C., took the chair at the second session, when radio and the cinema were discussed.
He commented on the great progress which has been made in radio technique since the War.

Mr. G. Ivan Smith, who has produced many talks on science in Australia and in the B.B.C.'s Empire Service, considered the difficulties with which a producer of science talks has to contend. He thinks that science must be introduced to the untrained listener by an emotional appeal. The listener must be made to 'sense' the close relation of science to his own personality by programmes on the chemistry of the body, the soil, plants, or the applied physics which create his material environment. Then the scientific worker must be induced to take infinite pains to interpret himself to his fellow citizens in language that can at once arrest their attention and be easily intelligible.

Sir Robert Watson-Watt sees the greatest obstacle to bringing science to the citizen in the lack of a common language. In using the radio as a medium for the explanation of scientific facts, it is most desirable that the personality of the speaker should be projected into the home audience. For this, high. quality transmission is a first consideration.

According to Dr. C. D. Darlington, science, as we now have it, is nothing less than the arrangement of knowledge for the benefit of mankind. For a hundred years science has been transforming the world, and for a hundred years government has been painfully stumbling behind. More than ninety per cent of the people who govern us are ignorant of the method and meaning of science. They have been educated in a pre-scientific age by an educational system which instead of integrating the future with the past has bent all its efforts to their separation.

After commenting on the strange oversight which excludes from the Board of Governors of the B.B.C. a representative of the profession which brought the radio into being, Dr. Darlington said that the first step is to establish a science committee to prepare, co-ordinate, and direct a science policy in broadcasting. This committee would have to think out how to raise the scientific interest and understanding of the public. It would address itself to the educable fraction of listeners, which Dr. Darlington thinks might be increased from 5 to 25 per cent. Programmes would be included to cover industry, housing, agriculture, food, medicine, health, education and social habits, biography and topical science news.

There should be plenty of time for such broadcasts. The 'Home' programme at present includes 7 hours of religious broadcasting a week and 20 minutes of scientific. The 'Forces' programme includes $1 \frac{1}{4}$ hours of religion and no science at all. Whatever the obstacle to scientific broadcasting may be, it is certainly not time.

Dr. D. MeClean, speaking as a representative of the Association of Scientific Workers, outlined a scheme for the general orientation of the B.B.C. programmes in order to convey the scientific attitude without dulling the appetite of the ordinary listener. $\mathrm{He}$ advocates the adoption of a general scientific outlook or method of approach in all discussions, social, economic, educational and informative, and also an increase in the specifically science programmes. He suggested that there should be a scientific worker as a regular commentator on passing events, and a permanent committee of representatives of the scientific profession to advise on and to develop ideas for the B.B.C. programmes.

Miss Mary Field discussed the principles of making a biological film, and the role of the biological film in 
education. She stressed the point that the biological film, as so many people tend to forget, is only a piece of educational equipment in the hands of the teacher. It cannot teach by itself or take the place of slow, painstaking personal observation and work. But for introductory or revision work, for showing movement of all kinds and for studying the behaviour of specimens, at all times of the year or over a period of years, it is invaluable-nor can biology be taught so well without it.

Mr. Paul Rotha sees a great future for scientific films in educating our political leaders, industrialists, Civil servants and others in whose hands lie the power to make use of science, and who are scientifically illiterate or obstinately anti-scientific. Films will also be needed for specialists in many fields who need to know how science affects their work, for example, farmers. A lead in scientific film-making has been given by the Ministry of Information, and certain industrial firms. The film industry itself must be induced to produce fil ms about science.

\section{Science as a Humanity}

Speaking from the chair on the history of h umanism, Prof. J. L. Myres maintained that : (1) from the beginnings of a humanistic outlook, in antiquity, and also at the revival of learning (in the fourteenth century), the natural sciences had undisputed and indispensable place among the humanities ; and (2) that they lost that place when the technological demands of modern industrialism claimed for them a status apart from the 'more humane studies', in the hope of producing experts and specialists in some one line of lucrative research at the age of twenty-two or so. He decried the overburdening of modern timetables, which left zoologists no time to read the "Origin of Species".

Prof. B. Farrington gave a brilliant interpretation of the first two hundred years of Greek science (600400 B.c.), when for the first time in history the idea of a scientific attitude to external Nature, to man and to society was conceived. Modern historians have conspired to describe their achievements as a miracle, a tribute no doubt to the brilliance of their ideas, but a sad comment on the success of their endeavour, which was to banish miracle from Nature. The originality of the Ionian method of explaining Nature was that it sought to interpret all Nature in terms of the familiar processes by which man himself exercises control over limited portions of Nature's domain. The things going on in heaven and under the earth were the same sort of things as were going on in the kitchen, in the workshop, in battle and on the farm. This way of explaining Nature belongs to a period when techniques were held in high honour in society and form an integral element in the culture of the dominant class. Ionian science changed its character, tending to become exclusively logical and mathematical when the growth of the institution of slavery freed the citizen from manual work and separated him from most forms of practical operational control of nature.

Mr. F. R. G. Duckworth, chief inspector of secondary schools for the Board of Education, thinks that the scientific approach and the artistic approach must be taught concurrently for the full understanding and appreciation of natural phenomena.

Dr. R. V. Southwell devoted his address to a consideration of the 'average man', to whom the exposition of science by the radio, cinema and press will in the future be addressed. The cultural value of science is in its development of a special kind of thinking, and it is some acquaintance with this 'scientific thought' which is wanted in the education of normal citizens, rather than the teaching of factual knowledge about science. It should be the aim of education to develop also other kinds of thought which are necessary for a fully developed personality : the thinking needed for an appreciation of the arts, the thinking trained by a study of languages, the thinking which reveals itself as wisdom in the affairs of life itself. It is in a truly balanced education of this kind that science should play its part.

Prof. W. E. Le Gros Clark considered the place of the biological sciences in the humanities, and how in general education they may be treated in particular relation to their bearing on human problems-the problems of the individual and collective living. Thus, the concept of organic evolution is of vital importance in emphasizing the unity of man with the organic world. The principles of heredity, dealt with by reference to laboratory experiments on insects and plants, can be applied to heredity as it affects man in the control of hereditary disease and the improvement of animal stock. Plant physiology can be related to agricultural problems and food production, animal physiology to human physiology. With the introduction of biological sciences into the general educational curriculum, biological problems which intimately affect human society will be more rapidly and satisfactorily solved, since the social conscience will have been awakened and inertia based on public ignorance will no longer be possible.

An account of the growth of discussion groups in the Army under the direction of the Army Bureau of Current Affairs was given in a paper by Mr. W. E. Williams, director of the Army Bureau of Current Affairs, read by Dr. O. J. R. Howarth. A.B.C.A. is an improvised experiment in mass education. The discussions, which are compulsory, and take place in working hours, cover a wide field of interest. The most popular topics are those which affect the individual. 'What does it mean to me?' is the approach which most quickly rouses attention and eloquence. The most frequent deficiency in the discussions is accurate knowledge, and the effects of cutting off education at the age of fourteen are often lamentably evident. As a war-time innovation, A.B.C.A. has already made a profound effect on the Army, and it is to be hoped that something of this experiment will survive the War and be incorporated into civil life in peace-time.

Dr. C. H. Waddington, whose paper was presented by Dr. D. P. Riley, envisages science not so much as one of the humanities but rather as potentially providing a point of view which can succeed that of the humanities as the ideological focus of the new society which is coming into existence. If science can formulate a view of man which, by emphasizing his essentially social nature, is profounder than that of the individualistic capitalist era, it will have played a by no means negligible part in bringing the new society to birth.

\section{Science and the Press}

At the final session, the chair was taken by Sir Richard Gregory, who dealt with some prominent characteristics of the scientific movement following the publication of the works of Mill and Darwin. These works had a great influence in releasing thought 
and inquiry from conventionalism and in revealing relationships between the nature of man and his environment. The foundation of NATURE towards the latter part of the last century was a landmark in promoting this movement.

Mr. Ritchie Calder, formerly science editor of the Daily Herald, was optimistic about the effect of the War on the mental attitude of the average reader, the average journalist and the average scientific man. The newspapers have been purged, scientific men have been drawn from their isolated position into public life and the average reader, through national service, has been given a new way of life and a new outlook. In a war of scientific weapons, they have become to a greater or lesser degree scientific. This new population will demand new treatment from the Press. He thinks that there will be a need for a British Institute of Scientific Information linked with similar organizations throughout the world, which will maintain a regular supply of scientific information for dissemination in the various countries. A similar idea was put forward by Mr. Henry Martin, of the Press Association.

Mr. J. G. Crowther put forward many suggestions for increasing the popular understanding of science, pointing out that there is no simple way of bringing this about. The improvement of science reporting in the Press depends on the simultaneous advance of several interests : the increasing interest and demand from the public; the effects of a higher standard of science teaching; the raising of the schoolleaving age; the recognition by owners and editors of newspapers of the growing importance of science; recognition by the State and philanthropic bodies of the necessity for better public understanding of science; the efforts of scientific men themselves to make their activities better known and understood, and the promotion of scientific interest which arises from the increasing mechanization of daily life. $\mathrm{He}$ advocates a full-time science editor for every newspaper, and a science news service providing reliable science news to all newspapers which subscribe to it.

The work which the Association of Scientific Workers is doing in publicizing science was described by Dr. D. S. Evans. The Association already has groups of people actively engaged in publicizing science in a large number of its branches, and steps have been taken to train members in the technique of popular science writing. Their aims are to counteract the perverted ideas of science in the Press as instanced by astrology pages and pseudo-scientific advertisements; to show the people what can be done by science during the period of reconstruction after the War and to protect the people from wrong systems of government offered in the light of arguments which appear to have a scientific background.

The Press was further criticized by Prof. J. B. S. Haldane, who said that more space is devoted to anti-science than to science. One of the first things to effect is a revision of the laws of libel so that some action could be taken against the lies perpetrated in patent medicine and other advertisements. $\mathrm{He}$ advocated a science news service; science features in every newspaper; a science reporter for every newspaper, and scientific and technical advisers attached to the staff of every newspaper to direct policy.

Mr. Francis Williams considered how the Press, instead of giving occasional publicity to sensational science news, could become a vehicle for the consistent interpretation to the public of the social impact of scientific development upon the world. $\mathrm{He}$ considered the possibility of producing a paper independent of advertisement revenue.

It was at this final session on science and the Press that Mr. H. G. Wells sounded the death knell of newspapers as we know them to-day. The time has gone, he thinks, when we shall have to buy four daily newspapers in order to find out what is being concealed from us. He visualizes a time not far off when we shall dial NEWS as we now dial TIM, and receive the latest bulletin over the wires. There are promising signs that the public are demanding informative matter to read and will no longer tolerate newspapers which give no news and exist for the commodities advertised in them. Bound books will disappear. Ideas will be ventilated in paper-covered books and pamphlets, sold at a price within the reach of all, and these will do what the newspapers have failed to do. Finally, old, stale, out-of-date textbooks must be burnt. The best-sellers of the future will be scientific books bringing to the citizen an awareness of the age in which he lives.

\section{B. M. H. TRIPP.}

\section{Message from Prof. Joffe, Vice-President of the Academy of Sciences of the U.S.S.R.}

I deeply regret being unable to avail myself of the kind invitation from the president of the British Association and from the British Council, conveyed to me by the British Ambassador, Sir Archibald Kerr. The reason preventing me from travelling to London is excellently expressed in the very subject of this Conference: "Science and the Citizen", which does not admit of my leaving my post and my work just now. . . .

The great pathos of the war for the freedom of my country and of all mankind has aroused in all of us a feeling of responsibility to our people. We know that science is no longer a plaything in our hands but a mighty weapon which, in these stern times, must serve the cause of defending humanity, ensuring mankind a happier future; and these are the tasks of science in days of peace also. The destinies of mankind are not determined by wars alone, as the Nazis preach; they are moulded by centuries of creative toil. In peace and in war-time our object is one-the happiness of our peoples, a happy life for all mankind. Science has already accomplished much towards this ; people hear each other and will soon see much of each other across the seas and oceans; in cinemas they are witnesses of the great battles of Stalingrad and Moscow and in Libya; within a few hours they are conveyed from one end of the country to the other ; they build ships in one month; they raise fruit and vegetables in the winter; they overcome pneumonia and contagious diseases. But at the same time we scientific men know better than anyone else what vast opportunities still lie dormant, how long is the path from scientific discovery to its ultimate realization.

What is needed is to shorten this process so that every citizen himself feels the full benefit of science and research.

We have long ago in the U.S.S.R. set ourselves this task. Our people, our Government have demanded its solution of us. With this aim in view we carefully thought out plans for our work, concentrating our forces on the most vital problems and seeking the most effective means to introduce into practical life 